\title{
AERODYNAMIC IMPROVEMENT OF CENTRIFUGAL COMPRESSOR STAGE INLET GUIDE VANES
}

\author{
Institute of Technical Mechanics \\ of the National Academy of Sciences of Ukraine and the State Space Agency of Ukraine, \\ 15 Leshko-Popel St., Dnipro 49005,Ukraine; e-mail: yukv@i.ua; zinevich7385@ gmail.com; boloto- \\ va_nataly@yahoo.com
}

This work is devoted to the aerodynamic improvement of elements of centrifugal compressor stages, which is topical because of their use in compressors of modern gas turbine engines. The aim of this work is to construct a technique for aerodynamic improvement of centrifugal compressor stage inlet guide vanes based on a numerical simulation of 3D turbulent gas flows and to verify its operability. The technique features: varying the 3D shape of an inlet guide vane using a parameter variable along the vane, formulating quality criteria as the mean integral values of the impeller power characteristics of the stage under consideration, and searching for an advisable inlet guide vane shape by scanning the variable range at points that form a uniformly distributed sequence. The basic method is a numerical simulation of 3D turbulent gas flows on the basis of the complete averaged Navier-Stokes equations and a two-parameter turbulence model. By the example of the inlet guide vanes of a centrifugal compressor stage, it was shown by computation that the proposed technique does improve the impeller power characteristics even in the case of a relatively small number of uniformly distributed points. This conclusion was verified by a subsequent calculation of the impeller power characteristics on a finer grid. On the whole, it was shown that varying the inlet guide vane shape has a pronounced effect on the impeller compression ratio and the operating range of the airflow rate, while leaving the impeller adiabatic efficiency almost unaffected. The results obtained are intended to be used in the aerodynamic optimization of elements of aircraft gas turbine engine centrifugal stages.

Keywords aerodynamic improvement, centrifugal compressor stage, inlet guide vanes, numerical simulation, power characteristics.

1. Vanyashov A. D., Zherelevich A. V., Grekhnev A. V., Dud'ev D. Ya. Results of experimental studies of a centrifugal compressor stage with an axial/radial flow impeller and inlet guide vanes (in Russian). Omsky Nauchny Vestnik. 2010. No. 2 (90). Pp. 105-108.

2. Vasil'ev Yu. S., Galerkin Yu. B., Soldatova K. V. Turbomachine flow passage optimization (by the example of centrifugal compressors) (in Russian). Problemy Energetiki. 2011. No. 9-10. Pp. 105-117.

3. Vanyashov A. D., Grekhnev A. V. Theoretical calculation of the power characteristics of a high-pressure centrifugal stage as a function of the inlet guide vane angle (in Russian), Omsky Nauchny Vestnik. 2012. No. 3 (113). Pp. 122-127.

4. Barysheva E. S., Demin A. E., Drynov O. N. Study of the flow in an aircraft engine axial-flow centrifugal compressor (in Russian). Aviatsionno-Kosmicheskaya Tekhnika i Tekhnologiya. 2014. No. 4 (111). Pp. 64-69.

5. Bondarenko G. A., Yurko I. V. Comparison of the results of a numerical and a physical study of centrifugal compressor inlet guide vanes (in Russian). Energenicheskiye i Teplptekhnicheskiye Protsessy i Oborudovaniye. 2011. № 5. . 90-94.

6. Kvasha Yu. A. Calculation of the 3D turbulent flow in supersonic compressor stage blade channels (in Russian). Teh. Meh. 1999. No. 1. Pp. 9-13.

7.Rublevsky . Yu., Plakushchy D. A., Pis'menny V. I., Kvasha Yu. A. Numerical study of a two-stage fan (in Russian). Vestnik Dvigatelestroyeniya. 2013. No. 2. Pp. 169-176.

8. Pis'menny V. I., Kvasha Yu. A. Calculation of the 3D air flow in a centrifugal compressor stage (in Russian). Teh. Meh. 2004. No. 2. Pp. 94-99.

9. Kvasha Yu. A., Zinevich N. A. Aerodynamic improvement of centrifugal compressor stage impellers (in Russian). Teh. Meh. 2019. No. 1. Pp. 57-67.

10. Sobol I. M., Statnikov R. B. Choice of Optimum Parameters in Multicriteria Problems (in Russian). Moscow: Nauka, 1981. 110 pp. 